\title{
Effect of Gender and Developmental Periods on Aggression Tendencies of Turkish Students: A Study of Meta-analysis
}

\author{
Mehmet Beyazsaclia
}

\begin{abstract}
With this study, it is aimed at examining the effect of the gender and developmental phases on the aggression tendencies of the Turkish students. In this context, the meta-analysis of the studies existing in the literature and covering the Turkish students has been conducted. The examined researches to be included in the analysis have been identified in accordance with certain criteria. As criteria, the following conditions have been sought: inclusion of the studies published between 2004 and 2015, inclusion of child, adolescent, and young adult students in the sample, giving the validity and reliability studies of the measuring tools, the studies being obtained from sources of the published theses and articles; and in the data, the arithmetic mean, standard deviation, and sample size being given. In the research, gender has been found effective on the general aggression scores, at significant level $\left(\mathrm{ED}_{\mathrm{avg}}=.280, p<.01\right)$, and against males at medium level. The general aggression scores from the moderator variables have been found to have a medium level of effect $\left(E D_{a v g}=.402, p<.01\right)$ on the childhood period, and to have the greatest effect against males.
\end{abstract}

\section{Keywords}

Turkish, meta-analysis, aggression, child, adolescent, young adult, student

Aggression, which, in the daily living, becomes a part of our lives, tends to be on rise, day by day, and to appear in front of us in every social domain. Aggression is generally defined as the attitude that aims at hurting somebody, physically or verbally, or destroying something (Acet 1997).

According to the theorists, who explain the nature of the aggression as instinct and drive, the aggressive behaviors show up as a result of indigenously stimulating the drive mechanism, which exists from birth and is biologically regularized (Fromm 1982). From the theoretical point of view, however, aggression is an energy, which has continually been accumulating in an organism. Knowing the root of the problem will bring us to the right starting point to cope with it. Thus, aggression for which foundations have been laid as from the childhood period of the human being will be avoidable. The objective of this research is to examine the level of effect of the aggression tendency observed among the Turkish students with respect to their gender and developmental periods.

An answer to the following question will be sought: In the direction of this general objective, what is the level of effect of the aggression tendency of the

aBritish University of Nicosia, Nicosia, North Cyprus

\section{Correspondent Author:}

Mehmet Beyazsacli, Nicosia Kerim Street, No. 16, British University of Nicosia, Nicosia, North Cyprus 
Turkish students with respect to their gender and developmental periods? It is expected that, in the light of the data obtained at the end of this research, some contributions are procured for the specialists, who have been conducting studies toward the risk bearing groups in the field.

In the research, primarily, whether the aggression tendencies create an effect size at significant level, or not, will be examined. At the second stage, through the use of the intermediate variables, whether, or not, the developmental periods create any effect size of differences at significant level between genders, will be examined.

\section{METHODOLOGY}

In this research, with the purpose of identifying the effect of gender and developmental periods on the general aggression tendencies, the meta-analysis of the researches that include the students in Turkey, has been carried out.

\section{Data Collection}

Data of the research have been gathered in February 2016. In order to have access to the researches took place in the study, the data bases such as: ULAKBIM, YÖK, Google Academic, EBSCOhost, and Web of Science, with key words such as: aggression, anger, and fury, have been made use of. At the end of these screenings, 46 theses and articles of the scope of child, adolescent, and young adult, have been access to. As criteria, the following conditions have been sought: giving place to the researches carried out between the years 2004-2015, the sample being related to child, adolescent, and young adult students, the levels of validity and confidence for the measurement tools being given, the studies being obtained from the sources of the published theses and articles, and the arithmetic mean, standard deviation, and sample sizes of the data being given.

\section{Data Analysis}

In the research, prior to the meta-analysis, in order to be able to make a general evaluation of studies related to the organizational citizenship and for identifying the researches to be included in the meta-analysis and in order to make it easy for the analysis of the data, primarily, a coding key system has been formed up. The research reference number, year of conduct of the research, subject of the research, type of the research, place of conduct of the research, the sampling group, sample size, measuring tools used, the people by whom the measuring tools developed, existence of the validity and confidence related evidences of the measuring tools utilized, values of the arithmetic mean and standard deviation according to the gender, seniority, and branch, have all been entered. Then, through the study of meta-analysis, the results of the research have been combined. The already set up coding keys were separately filled up by the researchers and then, by coming together, the results have been compared. Thus, it tried to prevent the errors made during the data entry. Also, within the framework of the determined criteria, a meeting related to the consensus on selecting the studies to be included in the meta-analysis has been arranged. Apart from the researchers, an assessment expert also attended the meeting.

In conducting an evaluation on whether, or not, there exists homogeneity among the researches included in the meta-analysis, the $\mathrm{Q}$ test has been utilized. For calculating the effect value in the meta-analysis, as a result of the distribution of the homogeneity, the random effect model has been used. The confidence interval of the study has been taken as .05 .

\section{RESULTS}

Before determining the effect value, through the researches included in the analysis, necessary examination has been conducted to find out whether 
there exists biasness, or not. The funnel dispersion that displays whether or not the publication is impartial, is presented in Figure 1.

When one examines the dispersion diagram in Figure 1, it is seen that: The studies gathered in the middle and upper sections and in both sides of the perpendicular line showing the combined magnitude of the effect, have been dispersed almost symmetrically therein. This finding reveals that, depending upon the result of the Orwin's reliable $\mathrm{N}$ analysis, there is no need to add a new research at the level of .05 determined for the general effect magnitude, and that it does not refer to the impartiality of the publication. However, whether or not there existing any biasness of the publication has also been examined, through the statistical data, with respect to the rank correlation relationship of Begg and Mazlumdar. At the end of the examination, it is seen that, the Tau coefficient is close to 1.00 and the value of $p$ is greater than the value of .05 (Tau $=.134<1.00$, $p=.18>.05)$ and that there is no publication biasness. In order to be able to decide on conducting the analyses of the effect size according to the model of fixed and random effects, the results of homogeneity-heterogeneity test given in Table 1 have been examined.

According to the results given in Table 1, because of the reason that the general aggression tendency does not show a heterogeneous distribution $(\mathrm{Q}=$ 248.540, $\mathrm{df}=45, p<.01)$, the random effects model has been utilized.

In Figure 2, a forest graphics for each of the study has been presented. In this graphics, the study weights have also taken place. The study weight is used for identifying the studies whose weights are relatively more compared with others (Dinçer 2014: 88). In Figure 2, the magnitude of the square representing each one of the studies shows the weight of the study. When one examines the given study weights, it is seen that the weights of the studies included in the research, have been very close to each other.
In Table 2, the findings regarding the effect of aggression tendency on gender have taken place. It has been found out that the level of effect of the aggression tendency has been at medium level $\left(\mathrm{ED}_{\mathrm{avg}}\right.$ $=.284, p<.01)$ and has had the greatest effect on males.

For the second problem of the research, the effect of the aggression tendency with respect to developmental periods has been examined whether it creates any difference, or not, at significant level. In Table 3, the data regarding the findings are presented.

In Table 3, it has been found out that the developmental periods have a significant effect on aggression tendencies at medium level and against males $\left(\mathrm{ED}_{\text {avg }}=.287, \mathrm{Q}=7.997, p<.05\right)$.

From the point of view of the developmental periods, the level of aggression of male children $\left(\mathrm{ED}_{\text {avg }}=.401, p<.01\right)$ has the greatest effect at medium level. The young adult males have been found to be at second rank of being effective at significant level $\left(\mathrm{ED}_{\mathrm{avg}}=.268, p<.01\right)$ and the male adolescents have been found to be at third rank of being effective thereat $\left(\mathrm{ED}_{\text {avg }}=.223, p<.01\right)$.

\section{CONCLUSIONS}

At the end of the research, it was observed that the aggression tendencies among the Turkish students, with respect to gender, have created a significant effect at medium level and against males. Also, it is seen that the level of aggression of the childhood period has the greatest effect at medium level and against males. Some literature findings have revealed the results that males' tendencies to violence have been relatively higher (Gündoğdu 2010; Uysal and Dinçer 2013; Gençoğlu, Kumcağız, and Ersanlı 2014). Some of the findings of the research, however, have been presented that there does not exist any significant difference (Ağlamaz 2006). Arslanoğlu (2012) indicated that the empathetic abilities are effective on aggression and that the increases in the empathetic 


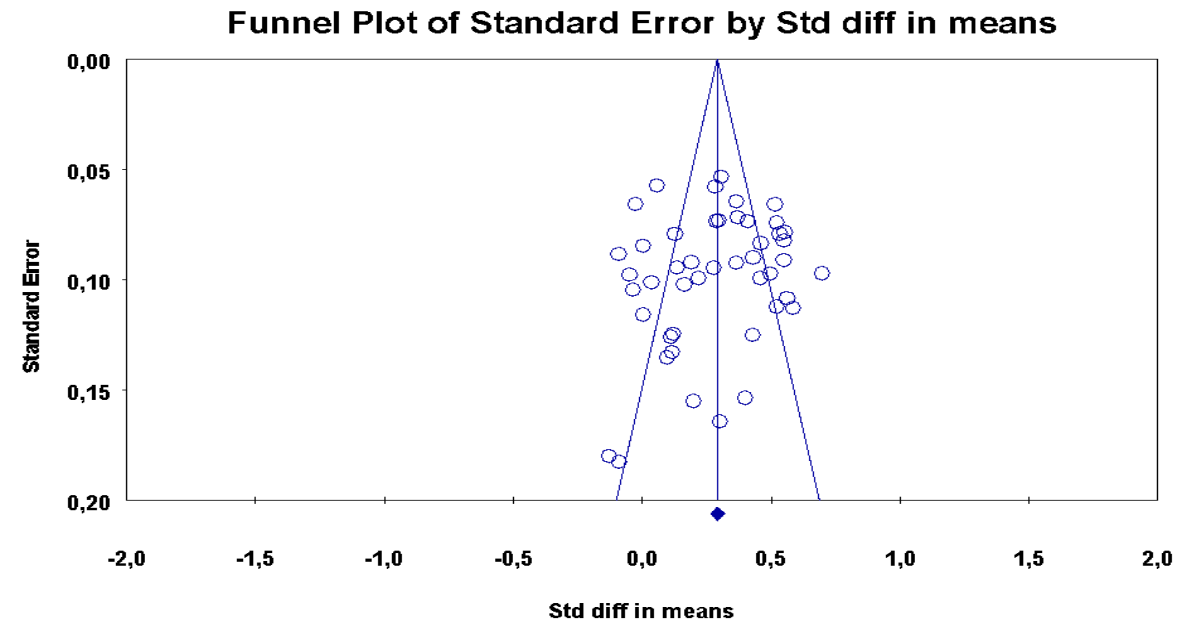

Figure 1. Funnel Dispersion Graph of Gender Variable.

Table 1. Results of the Analysis of the Fixed and Random Effects Model

\begin{tabular}{llllllll}
\hline Model & $\mathrm{N}$ & $\mathrm{Z}$ & $\mathrm{p}$ & $\mathrm{Q}$ & $\mathrm{df}$ & $\mathrm{p}^{*}$ & $\mathrm{I}^{2}$ \\
\hline Fixed & 46 & 22.701 & .000 & \multirow{2}{*}{248.540} & 45 & .000 & 81.902 \\
Random & 46 & 9.053 & .000 & & & & \\
\hline
\end{tabular}

Note: $p^{*}<.01$.

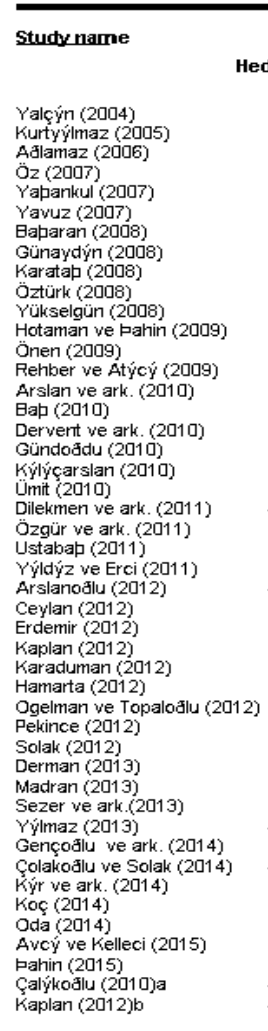

\begin{tabular}{|c|c|c|c|c|c|c|}
\hline & & & & and & & \\
\hline lges's & $\begin{array}{l}\text { Standard } \\
\text { error }\end{array}$ & Variance & $\begin{array}{l}\text { Lower } \\
\text { e limit }\end{array}$ & Jpper & Z. Value $p$ & 1. Value \\
\hline $\begin{array}{l}0,128 \\
0,520\end{array}$ & 0,079 & व,006 & $\begin{array}{l}-1,027 \\
0,775\end{array}$ & 0,283 & 1,616 & व,106 \\
\hline 0 & 0,057 & (1, & $\begin{array}{l}0.054 \\
-1,0\end{array}$ & 0,171 & 1,018 & 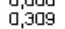 \\
\hline 0,584 & 0,113 & 0,013 & 0,364 & 0,805 & 5,189 & 0 \\
\hline 553 & 0,0 & व,व०ह & 0,399 & 0,706 & 7,054 & व, \\
\hline 口 & 0 & 0,008 & 0,254 & 0,606 & 4,792 & בנס, \\
\hline 0 & & 0,006 & 0,378 & 0,668 & 6,747 & 0,000 \\
\hline 546 & & , 007 & 0,967 & 0,709 & 6,676 & טa, \\
\hline 0,110 & 0,126 & , 1016 & $-1,136$ & 0,956 & 0,675 & 0,382 \\
\hline 0,204 & 058 & 0,09 & 0,171 & 0,997 & 4,919 & [व, \\
\hline & & & 10, & & & \\
\hline 0 & $\square$ & 1,009 & 0,506 & 0,660 & 7,194 & \\
\hline & 口 & & - 10,05010 & 0,9 & & \\
\hline & ( & (1005 & 0,263 & 0,5 & 5,5 & בוב, \\
\hline & & & 0,091 & 0,461 & & 0,003 \\
\hline & & & 0,155 & 0,441 & & 0,000 \\
\hline 197 & & 124 & -1,106 & 0,500 & & 0,202 \\
\hline & 口 & 115 & $-1,129$ & 0,364 & 969 & 0,999 \\
\hline & & 04 & 0,065 & 0,643 & 7,620 & בטם, \\
\hline & 11 & 06 & 0,970 & 0,727 & 128 & \\
\hline$-1,046$ & 0, & & - 299 & 0,143 & 20,490 & 0,624 \\
\hline & & & & 0,774 & & ד \\
\hline 0,4 & & & 02 & 年, & & (1,00 \\
\hline & & & & & & \\
\hline & & & & & & \\
\hline & & & & & & \\
\hline & & & & & & 100 \\
\hline 0,30 & 0 & 93 & 0,2 & & & בסבם \\
\hline & & & & & & \\
\hline 0,28 & 0 & 005 & 0,143 & 0,491 & 3,9 & טסם, \\
\hline ㅁ & & & ; & & & \\
\hline & & & & & & בסם, \\
\hline & & & $-\square, 1$ & & & \\
\hline & & & 0 & & & (1,099 \\
\hline 797 & 0,1 & 0,018 & $-0,1$ & 0,361 & 0 & 472 \\
\hline & 足, & & $\begin{array}{r}-1,1, \\
0,0\end{array}$ & 0,412 & 2,2 & (1928 \\
\hline & & & - 1, 4- & & & \\
\hline & & & & & & \\
\hline 四 & 0,068 & 0 & , 264, & 0,062 & $-1,0$ & 0,309 \\
\hline & & & & & & \\
\hline & & & & & & בנם, \\
\hline & & & & & & \\
\hline & & & - & & & \\
\hline 16 & 0,11 & & , & 0,362 & 1,593 & 0,111 \\
\hline -1, & 0,182 & 0,093 & $-0,445$ & 0,266 & - & 0,621 \\
\hline & 0,10 & 0,011 & $-1,241$ & 0,168 & - & 0,725 \\
\hline 0, 284 & $0, \square 31$ & 0,001 & 0,222 & 0,345 & 9,053 & व, \\
\hline
\end{tabular}

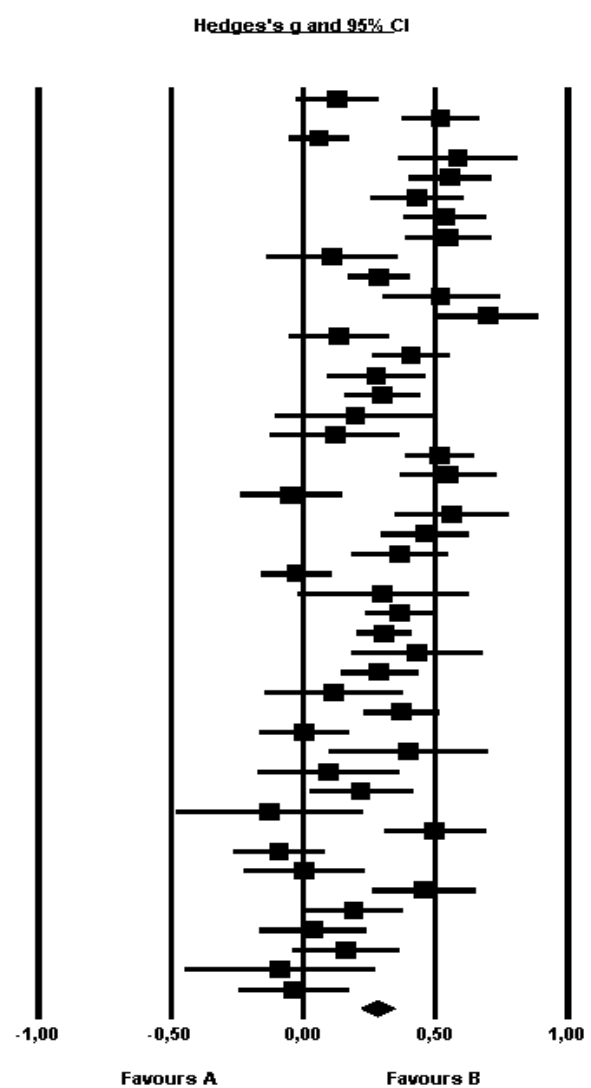

Relative Relative
weight weight

Figuer 2. Forest Graphics for the Effect of Aggression Tendency on Gender. 
Table 2. Results Related to the Effect of the Aggression Tendency on Gender

\begin{tabular}{|c|c|c|c|c|c|c|c|c|}
\hline Variable & $\mathrm{ED}_{\text {avg }}$ & $\mathrm{z}$ & Q & $\mathrm{I}^{2}$ & Serror & EDlower & EDupper & $\mathrm{p}^{*}$ \\
\hline Gender & .284 & 9.053 & 248.540 & 81.894 & .031 & .223 & .348 & .000 \\
\hline
\end{tabular}

Note: $\mathrm{ED}_{\text {avg: }}$ Average level of effect; Q: Total degree of homogeneity; EDlower-ED upper: In the confidence interval of $95 \%$ the limits of $E D_{\text {lower- }}-\mathrm{ED}_{\text {upper }} ; p^{*}<.01$.

Table 3. Effect of the Aggression Tendency on the Developmental Levels

\begin{tabular}{lllllllll}
\hline Variable & $\mathrm{ED}_{\text {avg }}$ & $\mathrm{z}$ & $\mathrm{Q}$ & $\mathrm{I}^{2}$ & $\mathrm{~S}_{\text {error }}$ & $\mathrm{ED}_{\text {lower }}$ & ED $_{\text {upper }}$ & $\mathrm{p}^{*}$ \\
\hline $\begin{array}{l}\text { Developmental } \\
\text { period }\end{array}$ & .287 & 9.842 & 7.997 & 81.902 & .029 & .230 & .344 & .018 \\
\hline
\end{tabular}

Note: EDavg: Average level of effect; Q: Total degree of heterogeneity; EDlower-ED $\mathrm{Epper}_{\text {: }}$ In the confidence interval of $95 \%$ the limits of ED lower-ED upper; $p^{*}<.05$.

levels of women create a decreasing effect on aggression. Arslan et al. (2010) mentioned that the aggression has correlation with the lack of self confidence and not taking responsibility, but the problem solving ability of and perseverance on women enable positive contributions to the decrease in the level of aggression. Avc1 and Kelleci (2015) have found out that the aggression on men has correlation with extroversive anger. It is indicated that, girls' aggression has been relatively lower while anger and verbal aggressions are relatively more thereof. Çolakoğlu and Solak (2014) indicated that men's aggression is relatively more than women's and that men have relatively lower level of empathetic abilities. It is indicated that aggression is seen relatively more on boys, and that aggression has negative correlation with motivation and hope. Dilekmen, Ada, and Alver (2011) have found out that the democratic family structure has got a decreasing effect on aggression. Şahin (2015) has found out that aggression has negative relationship with democratic family structure, positive relationship with authoritative family structure, and negative relationship with self respect. In conclusion, it is seen that, in the Turkish male students, the aggression level is effective at medium level and that this effect is at medium level in the childhood period. The state of the male aggression being relatively higher might have been as a result of the style of expressing himself and the form of his problem solving, which have been loaded on him within the Turkish cultural structure. Also, it might have been due to the effect of anger as a result of the men's feeling of being hindered within the authoritative family structure. It is suggested that the next researchers in the future intensify their studies on the reasons of aggression appearing in childhood period.

\section{References}

Acet, M. 1997. "Futbol Seyircisinin Sosyo-Kültürel Yapısının Şiddet Eylemine Etkisi, Voleybol ve Basketbol Seyircileri İle Karşılaştırılması" (Effect of the Socio Cultural Structure of the Football Spectators on the Activities of Violence, Their Comparison With the Volleyball and Basketball Spectators). Yayınlanmamış yüksek lisans tezi (Unpublished master dissertation), Marmara Üniversitesi Sağlık Bilimleri Enstitüsü Beden Eğitimi ve Spor AnabilimDal1, İstanbul (Department of Physical Education and Sports, Institute of Health Sciences, Marmara University, Istanbul).

Ağlamaz, T. 2006. "Lise Öğrencilerinin Saldırganlık Puanlarının Kendini Açma Davranışı, Okul Türü, Cinsiyet, Sınıf Düzeyi, Anne-baba Öğrenim Düzeyi ve Ailenin Aylık Gelir Düzeyi Açısından Incelenmesi” (Examining the Aggression Scores of the High School Students With Respect to: Self Disclosure Behavior, Type of School, Gender, Class Level, Parents' Educational Levels and Family's Monthly Income Level). Yüksek lisans tezi (Master dissertation), Ondokuz Mayıs Üniversitesi, Samsun (University of Nineteenth May, Samsun). 
Arslan, C., E. Hamarta, E. Arslan, and Y. Saygın. 2010. "Ergenlerde Saldırganlık ve Kişilerarası Problem Çözmenin Incelenmesi” (Examining Aggression and Interpersonal Problem Solving for Adolescents). Ilköğretim Online (Primary Education Online) 9:379-388.

Arslanoğlu, C. 2012. "Farklı Bölümlerde Öğrenim Gören Beden Eğitimi ve Yüksek Okul Öğrencilerinin Empatik Eğilim Düzeyleri ve Saldırganlık İlişkisinin İncelenmesi” (Examining of the Empathetic Tendency Levels and Aggression Relations of the Physical Education and Higher Education Students Studying at Different Departments). Yüksek lisans tezi (Master dissertation), Gazi Üniversitesi, Ankara (Gazi University, Ankara).

Avc1, D. and M. Kelleci. 2015. "The Relationship Between Anger, Aggression and Mental Symptoms of High School Students.” Araştırma Dergisi 1:34-42.

Çolakoğlu, F. and N. Solak. 2014. "Analysis and Examination of Aggression Levels and Empathetic Tendency Levels of Secondary School Students According to the Type of School and Gender." The Journal of Academic Social Science Studies 26:57-66.

Dilekmen, M., Ş. Ada, and B. Alver, 2011. "Aggression Characteristics of Second Stage Primary School Students." Gaziantep Üniversitesi Sosyal Bilimler Dergisi 10:927-944.

Dinçer, S. 2014. Uygulamall Meta Analiz (Applied Meta Analysis). Ankara: Pegem Akademi (Pegem Academy).

Fromm, E. 1982. Sevgi ve Şiddetin Kaynağ (Source of Love and Violence) (Translated by Y. Salman and N. İçten).
Istanbul: Payel Yayınevi (Payel Publications).

Gençoğlu, C., H. Kumcağız, and K. Ersanl1. 2014. "Ergenlerin Şiddet Eğilimine Etki Eden Ailevi Faktörler" (The Family Factors Affecting Adolescents' Violence Tendency). Literature and History of Turkish or Turkic 9:639-652.

Gündoğdu, R. 2010. “9. Sınıf Ögrencilerinin Çatısma Çözme, Öfke ve Saldırganlık Düzeylerinin Bazı Değişkenler Açısından Incelenmesi" (Examining of the 9th Grade Students' Levels of Conflicts, Anger and Aggression With Respect to Various Variables). Ç. U. Sosyal Bilimler Enstitüsü Dergisi (Çukurova University, Magazine of the Institute of Social Sciences) 19:257-276.

Şahin, E. 2015. "The Effects of Self-esteem Levels on the Relationship Between Agression Behaviour and Percieved Parents Attitude on the Adolescent Individuals." Yüksek lisans tezi (Master dissertation), Beykent Üniversitesi, İstanbul (Beykent University, Istanbul).

Uysal, H. and Ç. Dinçer. 2013. "An Evaluation of Physical and Relational Aggression During Preschool Period in Relation to Some Variables.” Education and Science 38:329-345.

\section{Bio}

Mehmet Beyazsacli, Ph.D., research scientist, Educational Sciences, British University of Nicosia, North Cyprus; research fields: anger, aggression, gender studies, self esteem, personality development, fatigue, adolescent problems. 